Portland State University

PDXScholar

Dissertations and Theses

Dissertations and Theses

2-22-1978

\title{
Assertion Training of Nursing Home Residents
}

Roberta Saul

Portland State University

Follow this and additional works at: https://pdxscholar.library.pdx.edu/open_access_etds

Part of the Geriatric Nursing Commons, and the Social Work Commons Let us know how access to this document benefits you.

\section{Recommended Citation}

Saul, Roberta, "Assertion Training of Nursing Home Residents" (1978). Dissertations and Theses. Paper 2679.

https://doi.org/10.15760/etd.2675

This Thesis is brought to you for free and open access. It has been accepted for inclusion in Dissertations and Theses by an authorized administrator of PDXScholar. Please contact us if we can make this document more accessible: pdxscholar@pdx.edu. 


\section{ISSERTION TRAINING OF NURSING}

\section{HOME RESIDENTS}

by

ROBERTA SATUL

A practicum submitted in partial fulfillment of the requirements for the degree of

MASTER OF SOCIAL WंORK 
TO THE OFFICE OF GRADUATE STUDIES AND RESEARCH:

The practicum advisor approves the research report, Assertion Training of Nursing Home Residents, by Roberta Saul, presented on February 22, 1978.

APPROVED:

Barbara Friesen, Practicum Advisor 


\section{ACKNOWLEDGEMENTS}

The author wishes to express appreciation to the staff at Elahan Mental Health Clinic and Center for Family Living without whose help and cooperation this study would not have been possible. I would like to extend particular consideration to Marva Schweibert for whose support and encouragement I am extremely grateful and to Nicki Smith for her patience and cooperation.

Thanks also to Barbara Friesen and Nancy Koroloff whose advice has been indispensable to the completion of this study. 
TABLE OF CONTENTS

PAGE

ACKNOWLEDGEMENTS. . . . . . . . . . . . . . . . . ii

TABLE OF CONTENTS ....................... . . iv

LIST OF TABLES. . . . . . . . . . . . . . . . . . . vi CHAPTER

I INTRODUCTION . . . . . . . . . . . . . . 1

II A REVIEW OF THE LITERATURE . . . . . . . . . . . 3

The Problems of the Elderly. . . . . . . . 3

A Historical Development of Assertion Training . . 5

Some Definitions of Assertiveness. . . . . . 7

Some Components of Assertive Behavior. . . . . . 8

Assertion Training Techniques. . . . . . . . 9

Techniques for Evaluating Assertiveness. . . . 10

Assertion Training of Institutional Populations. • 11

Assertion Training with the Elderly. . . . . . 12

Rationale for the Present Study. . . . . . . 13

III THE METHODOLOGY. . . . ............. 14

The Day Treatment Program. . . . . . . . . 14

The Assertion Training Module.......... 15

The subjects . . . . . . . . . . . 17

The Research Design. . . . . . . . . . 18

The Instrumentation. . . . . . . . . . 18

The Pilot Study. . . . . . . . . . . 20 
CHAPTER

PAGE

Administering the Instrument. . . . . . . 20

Hypotheses of the Study . . . . . . . . . 21

IV THE RLSULTS. . . . . . . . . . . . . . 22

The Adult Self Expression Scale . . . . . . 22

The Observer Data. . . . . . . . . . 26

V DISCUSSION AND CONCLUSIONS . . . . . . . . . 28

VI IMPLICATIONS FOR FUTURE RESEARCH . . . . . . • • 35

Addendum. . . . . . . . . . . . 36

FOOTNOTES . . . . . . . . . . . . . . . . . . . . 37

A SELECTED BIBLIOGRAPY. . . . . . . . . . . . . . . . 40

APPENDIX A: THE ASSERTION TRAINING PROGRAM. . . . . . . . . 43

APPENDIX B: THE ADULT SELF EXPRESSION SCALE ADAPTED FOR
THE ELDERLY . . . . . . . . . . . . . . 48

APPENDIX C: THE OBSERVER RATING FORM. . . . . . . . . 53 


\section{LIST OF TABLES}

TABLE

PAGE

I How Assertiveness Differs From Passivity and Aggressiveness on Behavioral Dimensions. . . . . . . . . 8

II Adult Self Expression Scale Scores for Each of the Four Testings. • • • • • • • • • • • • • • • • 23

III Mean, Median and Standard Deviation of the Adult Self Expression Scale for Each Testing . . . . . . . . 24

IV Means and Standard Deviations for the Adult Self Expression Scale When Administered to Non-institutionalized and Younger Sampling by Gay, Hollandsworth and Galassi in 1975. . . . . . . . . . . . . . . . . . 24

V Medians, Means and Standard Deviations of the Adult Self Expression Scale with the First and Second Testing Combined. . . . . . . . . . . . . . . . 25

VI Mean Scores for Each Week for Each Item Observed During Behavior Rehearsal in Assertion Training. . . . . . 27 
CHAPTER I

INTRODUCTION

An elderly woman comes to the doctor complaining about persistent pains in her left leg. With that bored look of "Oh, another one of those," the physician hurriedly goes through the motions of an examination. This is not the kind of case that excites his professional fervor.

"Not much we can do about it," he declares. "It's mainly your age. You just have to live with it." Plainly dissatisfied, the patient mutters,"But, doctor, my right leg is just as old, and it does not hurt." 1

The woman is attempting to assert herself. The concept of "assertiveness" has gained increasing attention over recent years. It has become a topic of many articles, books, classes and seminars and in many clinical settings "assertion training" has become a standard therapeutic tool. Researchers have discovered that college students, adults, patients in mental institutions and people with sexual dysfunctions can benefit from learning to be more assertive.

The National Organization for Women uses assertion training as a part of its strategy to overcome the oppression of women in our society. Certainly another group of people who suffer from oppression are the elderly. When a person in our society reaches age 65 , he or she may suddenly be perceived as of decreased worth and may face forced retirement and quite often may have to adjust to a lifestyle of poverty. If an elderly person's physical health begins to wane, a nursing home may suddenly become the day to day environment he or she must accept. So often an older person such as the woman in the previous example may 
have to cope with being ignored, pushed aside or branded with a label such as "senile". Assertion training can offer these people some new tools to let their needs, desires, feelings and expectations be made known.

The therapists in the Residential Care Program, which offers mental health services to residents of nursing homes, at Elahan Mental Health Clinic and Center for Family Living in Vancouver, Washington realized that assertion training might be one way to help their elderly clients gain more control over their lives and thus implemented an assertion training program. The following is an evaluation of that module which was introduced as part of the Elderly Day Treatment Program in 1977. 
CHAPTER II

\section{A REVIEW OF THE LITERATURE}

The literature review focuses on 1 ) the problems of the elderly, 2) the historical development of assertion training, 3) some definitions of assertiveness, 4) some components of assertive behavior, 5) assertion training techniques, 6) techniques for evaluating assertiveness, 7) assertion training of institutional populations, 8) assertion training of the elderly, 9) a rationale for the present study.

\section{THE PROBLEMS OF THE ELDERLY}

Hippocrates compared the stages of human life to nature's four seasons with winter being old age. ${ }^{2}$ Historically old age has been viewed as a time of physical and psychological decline. Until only recently theorists saw old age as falling somewhere on a continuum between illness and health and some such as Roger Bacon in the thirteenth century believed it was a disease. ${ }^{3}$ Now the general opinion is that aging is a process which all living things experience from birth.

Simone de Beauvoir describes the physical decline that comes with old age as including whitening of the hair, wrinkling of the skin, loss of teeth, compression of the spinal discs in the skeleton which causes a stooped appearance, muscular atrophy, and sclerosis of the joints, deterioration in the functioning of the heart, a decline in muscular strength and diminished sensitivity of the senses, among other changes 
in the body. 4 She speaks also of a decline in sexual ability in men but not in women. 5

On the psychological dimension, the theory of declining abilities is most prevalent. zumming and Henry propose a theory of aging as "an inevitable mutual withdrawal or disengagement, resulting in decreased interaction between the aging person and others in the social system to which he belongs." 6 Edinberg refutes this theory by suggesting that psychological detachment from living in old age is not an invariant stage of development but that it occurs because the older adult is accepting a cultural stereotype. ${ }^{7}$ Hasanyi supports this theory also and explains that sociological forces contribute to this stereotype. She states:

... there is a complete inconsistency with which it (our society) treats its older citizens; with great medical advances, it keeps them a:ive longer than ever, at the same time forcing them out. . of the labor market earlier, telling them that they are no longer needed, not wanted any more. 8

She believes that when opportunities are present to do so, a definite "re-engagement" occurs, not "disengagement", and that many of the symptoms commonly attributed to senility may be the result of sensory deprivation rather than age. 9

This stereotype of physical and psychological decline in old age affects psychiatric diagnosis and treatment of the elderly. Daley and Johnson found that the elderly population more often than any other age group received no treatment for their psychiatric diagnoses. 10 Hollingshead and Redlich had similar findings. ${ }^{11}$ Elderly people also more often received poorer prognoses of ever returning to maximum mental health. Although many elderly people do not receive treatment for problems diagnosed as psychiatric, others find themselves institutionalized in 
either a nursing home or mental hospital where they may lose many of their civil and legal rights. Garvin and Burger state:

It was estimated by a congressional committee recently that two out of fivs old people in California "hospitalized" in mental institutions should not be there at all, and yet they are forced to enjoy the comforts of the "madhouse" to their dying day. 12

These institutions in which the elderly may spend the last few years of their lives are often oppressive and dehumanizing. Erving Goffman describes the situation a person may encounter in a mental institution:

Mental patients can find themselves in a special bind. To get out of the hospital, or to ease their life within it, they must show acceptance to the place accorded them, and the place accorded them is to support the occupational role of those who appear to force this bargain. This self-alienating moral servitude, which perhaps helps to account for some inmates becoming mentally confused, is achieved by invoking the great tradition of the expert servicing relation, especially its medical variety. Mental patients can find themselves crushed by the weight of a service ideal that eases life for the rest of us. 13

Nursing homes are often equally as oppressive. Garvin and Burger refer to them as "halfway" houses between society and the cemetary, "pre-funeral" homes and beneficient prisons. 14

Assertion training could offer these people some skills to make their needs known and possibly to affect some changes in these social conditions.

A HISTORICAL DEVELOPMENT OF ASSERTION TRAINING

Andrew Salter was one of the first clinicians to discuss the therapeutic value of assertive behavior. In 1949 he published a book called Conditioned Reflex Therapy in which he discussed methods for helping neu- 
rotic patients overcome anxiety, depression and other problems through self-expression. ${ }^{15}$ His training procedures involved six excercises which Edinberg describes as:

1. feeling talk - the utterance of spontaneousily felt emotions

2. facial talk - using facial expressions to match affect

3. contradicting and attacking - when one's opinions differ from what another is expressing

4. deliberate use of the word "I"

5. expressing agreement when praised

6 . improvisation of responses to handle a variety of situations. 16

In 1958 Joseph Wolpe published Psychotherapy by Reciprocal Inhibition which had an even greater impact on the use of assertion training procedures. He demonstrated that patients could master their fears by learning assertive responses. A person who is expressing his or her feelings with vigor cannot at the same time feel anxious. ${ }^{17}$ Edinberg suggests some reasons why Wolpe had a greater influence than Salter on assertion training:

First, Wolpe's work came at a time when a behavioral approach to psychological problems was more acceptable to clinicians. Second, Wolpe did not advocate assertion training for every client. Third, Wolpe viewed assertion as a generalized trait, the latter point of view being upheld by subsequent research. Finally, Wolpe paid attention to potentially negative consequences of emitting assertive responses. 18

Lazarus later continued to develop the concept by using a combination of modeling behavior and role playing which he called "behavior rehearsal" to increase assertiveness. 19

Alberti and Emmons' book on assertiveness Your Perfect Right has become a popular tool not only for therapists, but for lay readers as we11. Coinciding with the women's movement Phelps and Austin wrote The Assertive Woman which provides the reader with a series of excercises to practice in order to learn how to be more assertive. 
SOME DEFINITIONS OF ASSERTIVENESS

The term "assertivenss" is a general term that may include a variety of specifir behaviors. Wolpe defines assertive behavior as referring "not only to more or less aggressive behaviors but also to the outward expression of friendly, affectionate and other nonanxious feelings. 20

Hollandsworth and Galassi describe assertiveness as "an active rather than a passive approach to life."2l

Alberti. and Emmons provide a more concise definition:

Behavior which enables a person to act in his own best interests, to stand up for himself without undue anxiety, to express his honest feelings comfortably, or to exercise his own rights without denying the rights of others.22

These authors further define assertiveness by placing it in the center of a continuum of behaviors with passive behavior at the one extreme and aggressive behavior at the other extreme. Table I summarizes a chart adapted from Alberti and Emmons by James Teigen which demonstrates how the consequences of assertive behavior differ from those of passive and aggressive behaviors.

Liberman and associates supplement the chart with this explanation:

The assertive individual defends his own rights and respects the rights of others, in contrast to the passive individual whose rights are violated and who is taken advantage of, or the aggressive individual who violates others' rights and takes advantage of others. The assertive person takes an active part in his work and social life; he chooses and achieves his goals, but not at the expense of others. 23 
TABLE I

HOW ASSERTIVENESS DIFFERS FROM PASSIVITY AND

AGGRESSIVENESS ON BEHAVIORAL DIMENSIONS

1. Has rights violated; is taken advantage of

Protects own rights and respects rights of others

2. Does not achieve goals

3. Feels frustrated, unhappy, hurt and anxious

4. Inhibited and withdrawn

5. Allows others to choose for him
Feels good about self; Has appropriate self confidence

Socially and emotionally expressive

Chooses for self
Violates rights;

takes advantage

of others

May achieve goals at expense of others

Defensive, belligerent; humiliates and depreciates others

Explosive; Unpredictably hostile and angry

Intrudes on others' choices 24

Assertive behavior encompasses many attributes, both verbal and nonverbal. Each author seems to focus on separate components of assertiveness. Some look only at response patterns while others try to break assertiveness down in to specific behaviors that contribute to a particular response. Lazarus includes only four kinds of assertive responses. These include:

1. The ability to say "no"

2. The ability to ask favors of others

3. The ability to express both positive and negative feelings

4. The ability to initiate, continue and terminate a conversation.25 
Paris and Casey outline 10 components of assertiveness. These

include:

1. Saying and thinking positive things about oneself

2. The ability to give honest compliments to others

3. The ability to express positive feelings

4. The ability io express negative feelings

5. The ability to accept compliments from others

6. The ability to state honest disagreements with ease

7. The ability to say "no"

8. The ability to insist on fair treatment from others

9. The ability to maintain contact with friends and acquaintances

10. The ability to initiate social contacts.

Liberman and his associates see response patterns of assertiveness as situation specific and tend to place greater emphasis on the nonverbal components, including:

1. Eye contact

2. Use of hands

3. Facial expressions

4. Body posture

5. Voice loudness

6. Speech fluency

7. Speech content. 27

All of these components, both verbal and nonverbal contribute to an over all attitude of assertiveness.

\section{ASSERTION TRAINING TECHNIQUES}

Few authors discuss the specific techniques used in training people to be more assertive. The most commonly used techniques are behavior rehearsal, modeling behavior and coaching. Liberman and his associates outline seven very specific steps that they use to teach assertiveness in groups: 1) identify the problems that the person has in communicating and expressing feelings, 2) target the training goals, 3) simulate the problem situation using other group members to role play the relevant 
scenes, 4) have the group give feedback (usually looking for positives), 5) use learning techniques such as explicit instructions, behavior rehearsal, modeling, inserting and fading prompts to shape behavior, 6) have the group give the person feedback on an improved performance. $\cdots$ and 7) give the person a homework assignment to practice the behavior in a real life situation. 28

McFall and his associates did.a series of studies on the effectiveness of behavior rehearsal, modeling and coaching. McFall and Marston found that behavior rehearsal is an effective technique. ${ }^{29}$. McFall and Lillesand discovered that subjects who participated in groups that received modeling and coaching along with behavior rehearsal scored significantly higher than those in groups that used behavior rehearsal alone when measured at the end of treatment. 30 Eisler, Hersen and Miller did a study which showed significant results when using a modeling-only procedure to train psyrhiatric patients to be more assertive. ${ }^{31} \mathrm{McFall}$ and Twentyman, on the other hand, found that modeling did not seem to add significantly to the training. 32

TECHNIQUES FOR EVALUATING ASSERTIVENESS

Presently several scales are available for measuring assertiveness. Most of these focus on the response patterns component of assertiveness. Wolpe and Lazarus developed the Wolpe-Lazarus Assertive Scale which consists of 29 "yes"/"no" responses. 33 Liberman and his associates developed a 30 item scale with "yes"/"no" responses. 34 These two scales are quick and simple to use but neither one has been standardized. Somewhat more complex is the Rathus Assertiveness Schedule which 
includes a six-point rating for each of 30 items as to how characteristic that response is to the person filling in the schedule. This assessment device has a high test-retest reliability $(r=.78 ; p<.01)$ and split half relıability $(r=.77 ; \mathrm{p}<.01) .35$

Galassi, Delo, Galassi and Bastien developed another reliable scale which they standardized on college students. It is appropriately titled the College Self Expression Scale. ${ }^{36}$ Later Gay, Hollandsworth and Galassi developed a similar scale for adults called the Adult self Expression Scale which proved to have high test-retest reliability when administered to adults ranging in age from 18 to 60 years (mean age $=25.38$ years). The study also demonstrated that the scale had moderate to high construct validity. ${ }^{37}$ The Adult Self Expression Scale, commonly referred to as ASES, consists of 48 items with a five point rating for each as to how the subject feels he or she would respond in a particular situation.

Some researchers have developed other methods for evaluating assertiveness than the popular self-rating inventories described above. Liberman and his associates devised an observer-rater form that looks at the nonverbal components of assertiveness such as eye contact and hand gestures. $^{38}$ McFall and Marston have employed live confederates either in role play situations or phone calls. 39 other researchers have used audio and video tape recordings for assessment.

\section{ASSERTION TRAINING OF INSTITUTIONAL POPULATIONS}

The research on assertion training of institutionalized subjects is minimal. Lomont, Gilner, Spector and Skinner did a study that resul- 
ted in a significantly greater decrease on clinical scales of the MMPI for those mental hospital patients receiving assertion training than of those receiving insight therapy. 40 Booraem and Flowers discovered a signifisant decrease in self reported anxiety among psychiatric patients receiving assertion training as opposed to a no treatment control group. 41

Lawrence Percell did two studies that showed that psychiatric patients exhibited an increase in self acceptance and a decrease in anxiety after receiving assertion training. ${ }^{42}$ Eịsler, Hersen and Miller did a study with 21 - 62 year old male psychiatric patients and found a significant increase in assertiveness after training. ${ }^{43}$

\section{ASSERTION TRAINING WITH THE ELDERLY}

The research on assertion training with the elderly is even more minimal than that for institutional populations. Mark Edinberg conducted two experiments. In the first he attempted to develop and standardize an assessment device for measuring assertiveness of elderly people. From interviews, observations and written responses of senior center staff and clientele he created a list of sample situations that elderly people might be likely to face, and a list of four or five possible responses to each situation. His attempt to standardize it as to its validity and reliability was unsuccessful. He also developed several role play situations during which expert judges could rate the subject's responses on an assertion scale. ${ }^{44}$

In his second experiment Edinberg developed and evaluated an assertion training program for the elderly. He did not find any signi- 
ficant post treatment differences among assertion training groups, discussion groups and no treatment controls. 45

RATIONALE FOR THE PRESENT STUDY

Nan Corby published an article which discusses some possible ways that assertion training might benefit the elderly. She suggests that it might address two major problems that elderly people face. These are loneliness and being ignored. She states:

Since it has been noted that assertion problems often underlie mood disturbances, hypochondria, low self-esteem and complaints of being pushed around and those problems appear with high frequency among the elderly, assertion training appears to be worthy of consideration as a treatment approach for older adults with these problems. Similarly, sexual dysfunction is not limited to young adults or the middle aged any more than is sexual interest. Where lack of assertiveness contributes to a dysfunction, assertion training would seem to be an appropriate part of the treatment, no matter what the age of the client. 46

She adds later:

The activity and relationship invitation techniques of assertion training can be particularly effective in enhancing social contacts and increasing intimate relationships among the elderly. 47

Since so little research has been done on the effects of assertion training with elderly people or institutionalized populations, the staff at Elahan Mental Health Clinic and Center for Family Living in the Residential Care Program wanted to know whether this technique should be included as a regular part of their day treatment program or whether it would be just a waste of time and money. This study is an account of an evaluation of a pilot assertion training program for the elderly day treatment population. 
CHAPTER III

THE METHODOLOGY

This section focuses on 1) the day treatment program, 2) the assertion training module, 3) the subjects, 4) the research design, 5) the instrumentation, 6) the pilot study, 7) administering the instrument, 8) the hypothesis of the study.

THE DAY TREATMENT PROGRAM

Elahan offers a day treatment program for elderly people which meets four afternoons a week and offers group and individual therapy along with training in basic living skills such as cooking, shopping, budgeting, transportation and socialization skills. The clientele are primarily nursing home residents who have psychiatric diagnoses and have been referred by either nursing home staff or their own physicians for various reasons. Some have exhibited bizarre behavior while in the nursing home such as hallucinating or acting out aggressively, others were notably depressed or withdrawn and may have made suicide attempts. At the time of this study, the clients attended day treatment voluntarily, were all ambulatory and in relatively good physical health. One long range goal of day treatment for these people was de-institutionalization. The program staff hoped to achieve this goal by facilitating the psychological growth and skills training necessary for those clients 
who were physically capable of moving from the nursing homes to more independent living situations.

\section{THE ASSERTION TRAINING MODULE}

The day treatment program staff felt assertion training might assist their clients in achieving greater independence from their institutional environment and asked this author to develop an assertion training module as well as an assessment device for measuring its effectiveness that might be incorporated into the day treatment program.

The module lasted for eight weeks of four sessions per week of about one and one half hours duration each. These assertion training sessions took place during the time that had previously been spent on group therapy (usually discussion with some mild insight therapy) and regular group therapy was deleted for these eight weeks. The other aspects of the day treatment program continued as usual including the same amount of time spent on individual therapy and basic living skills training as previously.

The assertion training module had eight objectives adapted from

Paris and Casey to which it addressed itself. ${ }^{48}$ These included:

1. An.increase in the ability of clients to think and talk about themselves in a positive way,

2. An increase in the ability of clients to express and receive honest compliments,

3. An increase in the ability of clients to express their feelings and opinions, both positive and negative,

4. An increase in the ability of clients to ask favors of others, 
5. An increase in the ability of clients to state honest disagreements,

6. An increase in the ability of clients to say "no",

7. An increase in the ability of clients to demand fair treatment,

8. An increase in the ability of clients to initiate and maintain social contacts.

The module focused on a different objective each week with some periodic review of what had been learned previously.

The training techniques consisted primarily of behavior rehearsal with some coaching and modeling. A typical session began with a brief introduction of the concept to be learned followed by role playing a situation that encompassed the concept and giving a homewark sisign-.. ment to practice the new behavior in a real life situation. At the beginning of each session subjects discussed their homework assignments, including their own reactions and the reactions of others to their new behavior. Staff kept track of completed homework assignments and behavior rehearsals performed during group sessions so that subjects would periodically receive small "reinforcers" for satisfactory participation. These reinforcers consisted of items from a list that each subject developed at the beginning of the training. Items ranged anywhere from new lipstick or nail polish to banana splits or candy bars. The trainers consisted of two therapists employed by the clinic to facilitate the day treatment program as part of their responsibilities and various student volunteers including a graduate student in counseling and two graduate students in social work. Both of the employees of the clinic were social workers. All trainers received a set of guidelines on the format of the assertion training module and partici- 
pated in an orientation before assertion training began.

THE SUBJECTS

When the inctial data collection took place ten people attended day treatment. Another woman joined at the time of the second data collection point just before assertion training began and was added to the study. At the end of the study one of the original ten subjects' data had to be discarded as invalid because she had consistently marked the same category regardless of the question on two of her questionnaires. This resulted in a total of ten participants, seven females and three males. Since these people were fairly representative of the kind of person who participates in day treatment they served as the sampling' unit for the study.

Subjects ranged in age from 44 to 73 years old. The mean age was 62.82 years. All were caucasian and either single, divorced or widowed, except for one woman who was married by common-law. Six subjects had only grade school educations, three had high school educations and one had a college degree. All subjects but one resided in one or the other of two nursing homes in Clark County. Three were from Meadowglade Nursing Home and seven were from Columbia View Manor. One woman lived at home with her mother. All but four of the subjects had been hospitalized for psychiatric treatment prior to their present stay in the nursing home. The psychiatric categories varied. Three had labels of schizophrenia, three had some brain damage, two were depressed, one was mildly mentally retarded and one had the label involutional melancholia. All subjects were on fixed incomes, either welfare or social security 
and were from either poor or working class backgrounds.

THE RESEARCH DESIGN

Since the diy treatment group is small it was impossible to create a control group so data collection took place at specific intervals before and after implementation and termination of the assertion training module in a quasi-experimental time series design. The first data collection occurred one month before the assertion training program began. The second data collection was right at the beginning of assertion training. The third took place immediately at completion of the assertion training program and the final data collection was one month following termination of the program.

Process data collection also took place on weekly intervals during the training. This consisted of an observer rating form that was completed by the same two staff members every Monday during the eight weeks of assertion training while the subjects role played specific situations where they could practice asserting themselves.

This evaluation only measures behaviors that can either be reported or measured within the treatment setting and makes no attempt to address generalization of the behaviors outside the treatment setting.

THE INSTRUMENTATION

A self report inventory adapted from the Adult Self Expression Scale served as the major assessment device (see Appendix B). This instrument includes questions which address each of the eight objectives of 
the assertion training program. Subjects responded to the same 48 questions asked in the ASES with the exception that certain words were changed to make the questions more relevant to situations that elderly people might face. Changes included deleting the work "parents" and substituting "children" because most elderly people do not have parents who are still living and their children often take on some of the parental roles when they become less able to care for theunselves in an independent environment. Another change was to substitute the word "nurse" for "boss" because none of the people participating in the study were employed and in the institutional environment the nursing home staff served in a similar authority role to that of a boss in a working environment. These changes in the instrument may affect its validity and reliability.

The instrument also needed some revision to compensate for the failing vision of some of the subjects and the low education level of others. Large print type served to make it easier to read. In order to simplify the questionnaire even more the five possible response categories followed immediately after each question on the same sheet of paper rather than on a separate answer sheet as in the original ASES questionnaire.

The other instrument used in the study consisted of a form to be completed by observers that looked at specific behaviors. Two observers, one, a therapist and the other, a student rated each subject every Monday while the subject role played. The specific behaviors observed included eye contact, voice volume, perceived level of anxiety and an assessment as to how assertive the subject appeared. (see Appendix C) . 
This rating scale consisted of a continuum from one to ten for each item. The same two observers consistently rated each subject on the continuum for each category throughout the training and were not allowed to see how they had rated any of the subjects during the previous sessions. No inter-rater reliability study was done, however.

\section{THE PILOT STUDY}

Nine residents at Meadowglade Nursing Home who participate in an outpatient group for the elderly through Elahan served as subjects in a pilot study using the adapted ASES. The study was primarily for the purpose of testing the scale to see whether the elderly people would be able to read and understand the questions and what, if any, problems might occur. None of these nine subjects were involved in the day treatment program but their therapist perceived that they were all of about the same educational levels and abilities as the day treatment group. The pilot study demonstrated that all but three of the subjects were able to complete the inventory on their own after receiving brief instructions from this author. The other three had trouble reading and were able to complete the questionnaire when this author read each item and the possible responses to them. The questionnaire took more time for these subjects to complete than was originally anticipated and motivation of some subjects to complete the qustionnaire seemed low.

\section{ADMINISTERING THE INSTRUMENT}

This author briefly explained the purpose of the research and how 
the questionnaires would be utilized each time they were administered. Subjects then received the instructions to respond to each item by imagining that they were in the particular situation described by the question. They were to then imagine how they would respond in that situation and not how they thought they should respond. To increase motivation among the day treatment subjects each subject was allowed to take a coffee break (a normal part of the day treatment program) upon completion of his or her questionnaire.

Seven subjects were able to complete the questionnaire on their own without any difficulty. Two subjects could not see clearly enough to read the questions and a third subject had difficulty understanding the questions. These three subjects sat at a separate table with this author who read the questions to them. Every attempt was made to keep any reader bias at a minimum and avoid interpretation of the questions. All three subjects were able to complete the questionnaire successfully using this method.

HYPOTHESES OF THE STUDY

The main hypothesis of the study is that subjects would have significantly higher scores on the ASES after the assertion training than they did before, meaning that they would perceive of themselves as being more assertive after the training.

An ancillary hypothesis is that the subjects would have higher scores on the observer rating forms toward the end of the training than they did at the beginning, meaning that observers would perceive of them as being more assertive also. 
CHAPTER IV

THE RESULTS

This section focuses first on the results of the Adult Self Expression Scale and then on the results of the observer rating forms.

\section{THE ADULT SELF EXPRESSION SCALE}

Table II shows the four test scores for each subject. Final scores were not available for subjects number four and seven because they were no longer in day treatment at this final testing even though they had completed the assertion training program with the other subjects. Subject number seven was in the hospital with a broken arm and subject number four had just decided to withdraw from day treatment. No preliminary test score was available for subject number ten who entered the program too late to allow collection of this data.

The most interesting aspect of these scores is that six of the ten subjects show a marked increase in scores from the first testing to the second testing both of which took place before the assertion train= ing began. The scores then tend to level off between the second and .. third testings and the third and fourth testings. 
TABLE II

ADULT SELF EXPRESSION SCALE SCORES FOR

EACH OF THE FOUR

TESTINGS

\begin{tabular}{lcccc}
\hline Subject & Testing \#1 & Testing \#2 & Testing \#3 & Testing \#4 \\
\hline & 99 & 102 & 106 & 95 \\
One & 113 & 131 & 120 & 113 \\
Two & 102 & 108 & 105 & 89 \\
Three & 70 & 68 & 87 & - \\
Four & 94 & 90 & 88 & 92 \\
Five & 114 & 119 & 119 & 131 \\
Six & 96 & 98 & 102 & - \\
Seven & 100 & 139 & 130 & 124 \\
Eight & 111 & 96 & 100 & 94 \\
Nine & - & & 97 & 97 \\
Ten & & & & \\
\hline
\end{tabular}

Table III shows the medians, means and standard deviations which demonstrate the trend more clearly of an increase between testings one and two and a leveling off between testings two and three and a slight drop between testings three and four. The mean score increases 6.3 points from the first testing to the second. The third testing shows a drop in the mean of .4 points and the fourth testing shows a drop of 1.0 points in the mean.

The means and the medians are all close together on the first three tests indicating a normal distribution of scores. The final median is 8.4 points below the final mean indicating that this latter group of scores may be skewed. This might in part be attributed to the fact that two scores are missing and that the sample size is so small.

The standard devilations are all large indicating much variance among scores which seems to be in keeping with the results that Gay and 
his associates found when they administered the ASES to 464 subjects in 1975. 49 Table IV shows the findings of their study which gives some norms for comparison "with the findings of this study. The subjects in Gay et. al.'s stuuy are non-institutionalized people ranging in age from 18 to 60 years. As could be expected the scores of the subjects in this study fall several points below these norms.

TABLE III

MEAN, MEDIAN AND STANDARD DEVIATION OF THE ADULT SELF EXPRESSION SCALE FOR EACH TESTING

\begin{tabular}{lrrrr}
\hline Statistic & Testing \#1 & Testing \#2 & Testing \#3 & Testing \#4 \\
& & & & \\
\hline \multirow{2}{*}{ Median } & 99.0 & 104.5 & 103.5 & 96.0 \\
Mean & 99.5 & 105.8 & 105.4 & 104.4 \\
Standard Deviation & 13.1 & 20.5 & 14.0 & 17.1 \\
\hline
\end{tabular}

TABLE IV

MEANS AND STANDARD DEVIATIONS FOR THE ADULT SELF EXPRESSION SCALE WHEN ADMINISTERED TO NON-INSTITUTIONALIZED AND YOUNGER SAMPLING BY GAY, HOLLANDSWORTH, AND GALASSI IN 197549

\begin{tabular}{lrrr}
\hline Sample & $\mathrm{n}$ & mean & standard deviation \\
\hline \multirow{2}{*}{ Sex: Male } & 192 & 118.56 & 18.57 \\
Age: 19 years or younger & 117 & 114.78 & 21.22 \\
20-24 years & 149 & 113.74 & 19.35 \\
25-29 years & 89 & 115.48 & 21.21 \\
30 years or older & 105 & 120.73 & 20.76 \\
Marital Status: Single & 229 & 116.77 & 18.76 \\
Married, Separated, & & 114.26 & 20.60 \\
& 217 & 118.49 & 19.62 \\
\hline
\end{tabular}


The substantial increase in scores from the first testing to the second testing may be attributed to the fact that some test training effect could have occurred. Some subjects learned how to respond to the questions more appropriately by the second time they answered the questionnaire because staff had been discussing the assertive training with them during the interim in order to prepare them for it. In order to take this possible effect into consideration the first two test scores, both of which were obtained before assertion training began, were averaged together to produce one initial score for comparison with the latter two post assertion training scores.

Table $V$ shows that an increase of 2.75 points occurs between the first two sets of data when averaged and the third testing, and an . increase of 1.75 points from these two testings to the final testing. When applied to the difference between these first two testings and the third testing $t=1.14$ which is not significant at any level of probability.

TABLE V

MEDIANS, MEANS AND STANDARD DEVIATIONS OF THE

ADULT SELF EXPRESSION SCALE WITH FIRST

AND SECOND TESTING COMBINED

Statistic Testings \#1 and \#2 Testing \#3 Testing \#4

\begin{tabular}{lccc} 
Median & 102.0 & 103.5 & 96.0 \\
Mean & 102.65 & 105.4 & 104.4 \\
Standard Deviation & 15.7 & 14.0 & 17.1 \\
\hline
\end{tabular}


THE OBSERVER DATA

Because no reliability study was done with the instrument and no inter-rater relahility study was done between the two observers, these results cannot be taken too seriously. They do, however, give some indication as to whether the assertion training may have had any effects not measured by the ASES. Table VI represents mean observer rating scores on each of the four items observed: eye contact, voice volume, anxiety and over all assertiveness.

The trend of the scores shows an increase from the first four weeks of assertion training to the scores recorded during the last four weeks of the training. All scores except eye contact show an increase when comparing the first week to the last week. The anxiety score shows the highest increase from week number one to week number eight meaning less anxiety must have been apparent to observers at the end of the training than was apparent at the beginning.

Another striking effect about this data is that a noticeable drop in all scores except eye contact occurs between the first week and the second week. This may be attributed to the observers becoming more attuned to the behaviors which they were observing much the same way that training effect may have occurred with the other instrument used in this study or to the subjects' uncomfortableness with the role playing which was a new behavior to them. The graph in Figure 1 more descriptively illustrates the upward trend of the over all mean scores. 
TABLE VI

MEAN SCORES FOR EACH WEEK FOR EACH ITEM

OBSERVED DURING BEHAVIOR REHEARSAL

IN ASSERTION TRAINING

\begin{tabular}{|c|c|c|c|c|c|c|c|c|}
\hline Behavior & \#1 & $\# 2$ & $\# 3$ & $\# 4$ & \#5 & \#6 & $\# 7$ & \#8 \\
\hline Eye contact & 6.6 & 6.8 & 5.1 & 7.1 & 6.0 & 7.5 & 6.3 & 7.1 \\
\hline Voice volume & 7.5 & 5.3 & 5.6 & 6.5 & 6.0 & 6.0 & 6.3 & 6.7 \\
\hline Anxiety & 5.8 & 4.8 & 4.6 & 5.4 & 5.5 & 6.2 & 6.0 & 7.0 \\
\hline Assertiveness & 6.0 & 4.6 & 4.6 & 6.3 & 5.9 & 6.7 & 6.7 & 6.4 \\
\hline Over all means & 6.5 & 5.4 & 5.0 & 6.4 & 5.9 & 6.6 & 6.4 & 6.8 \\
\hline
\end{tabular}

Score

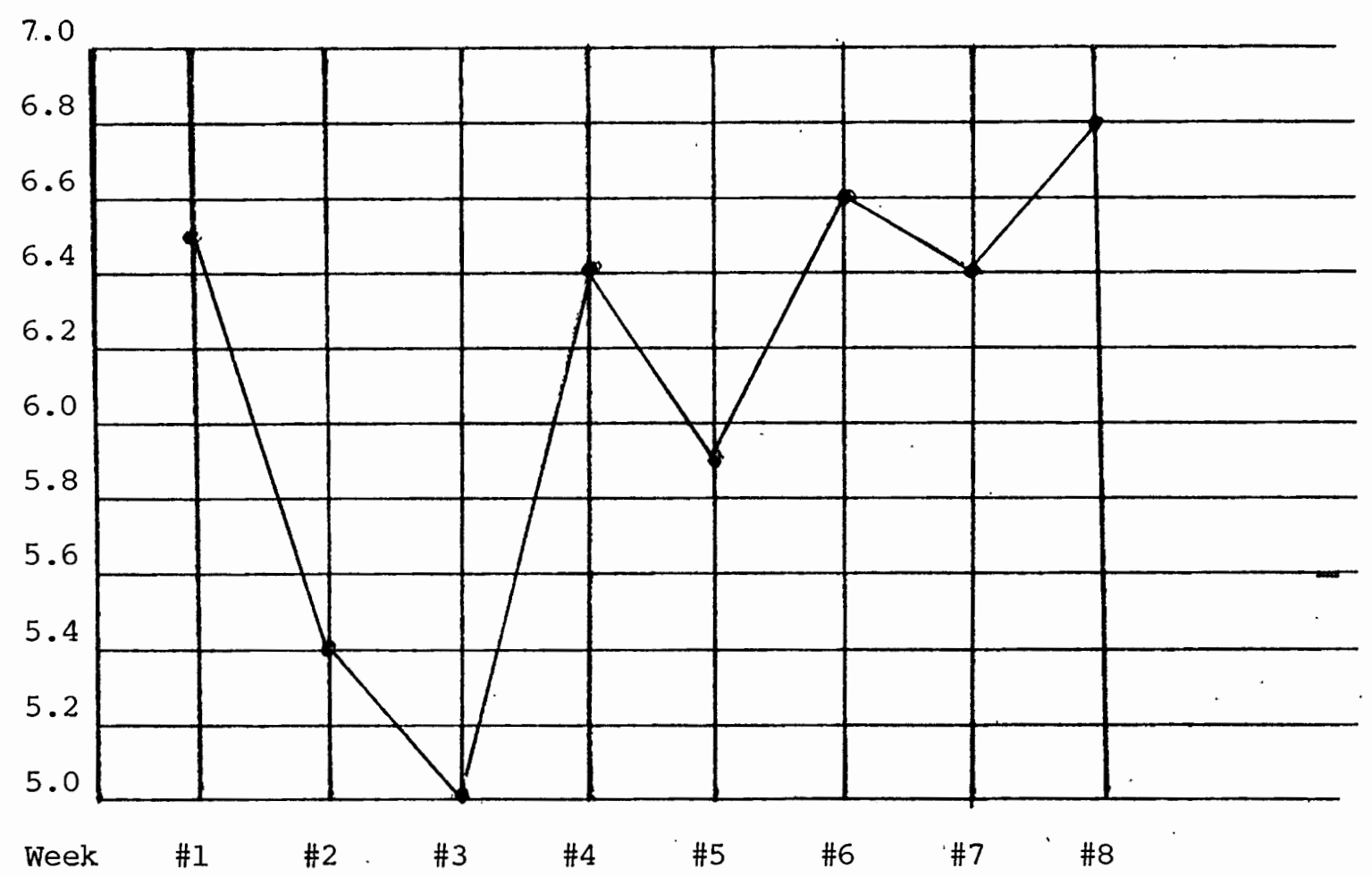

Figure 1. Over all mean scores for each week of assertion training as recorded by observers during behavior rehearsal. 


\section{DISCUSSION AND CONCLUSIONS}

Generally, the study accomplished its main purpose of evaluating the assertion training program for the elderly, institutionalized adults. Though the Adult Self Expression Scale did not yield any statistically significant differences between the pretest and post test scores, both this instrument and the observer rater forms indicated some slight positive change.

At least five factors may have contributed to the nonsignificance of experimental results: 1) the small sample size, 2) problems with the measurement procedures, 3) motivation of the subjects, 4) selection of the subjects and 5) problems with the training procedures.

One major problem with this study was the small number of subjects involved. Since the day treatment program generally consists of no more than 10 , to 15 participants it would be necessary to repeat the study several times over a period of years with different subjects in order to have a large enough sampling to be ideal.

It's also possible that the measurement device was not able to detect the actual changes that did occur. While many of the 48 questions on the Adult Self Expression Scale related directly to one or more of the specific objectives of the training, many of them dealt with specific situations that the subjects of this study seldom or never face 
presently in their lives. For example, the questions pertaining to one's spouse, boyfriend or girlfriend were not relevant to most subjects as all of them were either divorced, widowed or had not married at the time of the study and only two of them had any current on-going romantic relationship with a member of the opposite sex. Also, questions about going out to restaurants or stores were hard for some subjects who seldom left the nursing home to respond to. It is possible that some subjects may have responded to the questions the way they thought they should respond rather than how they actually would behave in the given situation, even though they were instructed not to do so. For some subjects the format of the questionnaire may have been too complex and a scale using only the answers "yes" or "no" rather than five responses from which to choose might yield better data in future studies with this population.

Another problem was that of the motivation of the subjects. Although all subjects were participants in the day treatment program voluntarily, participation in the assertion training and the study were not introduced in such a way as to allow them much freedom of choice of whether to participate or not. It was automatically assumed by staff and subjects alike that since they were participating in day treatment they would participate in the assertion training and the evaluation as part of their treatment. Though subjects could have refused to participate if they wanted, few, if any, would have gone against the authority of the staff. In this sense assertion training creates a kind of double bind situation. A subject who refused to participate in the 
training may have been showing an ability to be assertive and thus, less of a need for the assertion training but at the same time may have suffered the disapproval of the staff. Because of this dilemna and the tendency among this group of people to obey those in authority without question, some subjects may have participated in the study and the training who were not really interested or motivated to change their behaviors. The staff attempted to increase motivation by supplying reinforcers in the form of small, inexpensive items that subjects specifically identified as desirable and that they otherwise probably would not have received, for completion of certain numbers of assigned tasks such as homework and behavior rehearsal in the group. These rewards may not have been enough to motivate all subjects who were not otherwise motivated. In future studies the researcher may want to make it more explicit to potential subjects that participation is voluntary. This might better insure that the subjects who do participate will be more highly motivated. It also may reduce an already small sample size. Subject selection proved to be a problem in that two subjects suffered from brain damage and as a result had difficulty remembering things including homework assignments. This difficulty remembering remained a problem through out the training and may have interfered with the ability of each of these two subjects to learn new responses. The mild mental retardation of another subject could also have interfered to some extent, especially in understanding some of the concepts that were presented. This, however, was much less obvious a problem than the inability to remember of the other two subjects. A future study might 
either adapt the training to compensate for these problems by having someone at the nursing home to remind the brain damaged subjects to do their assignments or exclude such subjects if it is possible to do so without greatly afiecting the sampling.

Finally, some problems with the training procedures may have contributed to the non-significant results. Though one staff member served as the primary therapist during most of the training sessions, another staff member filled in as primary therapist at least one of the four sessions each week and more often than this on a couple of occaisions. In addition to this a different co-therapist assisted the primary therapist each day of the week. This lack of consistency of trainers may have contributed to a decreased effectiveness of the training. Also, all of these trainers were at least 20 to 30 years younger than most of the subjects which left them with an absence of role models their own age with whom they could identify. This age difference may also have hindered their learning new behaviors. Using an elderly therapist or video taped presentations of older adults behaving assertively might be useful to help remedy this problem. One other training procedure that lacked consistency was the reinforcement schedule. Though subjects did receive praise and social reinforcement consistently throughout the training, the plan was to reinforce them with material rewards once a week for successes. In actual practice this did not occur as consistently as planned and may also have contributed to non-significant treatment results by adversely affecting the motivation of some subjects.

Though no statistical tests were done with the observer rating 
forms, the results indicate that the clients may have derived some benefit from the assertion training. Since no reliability study has been done on this data collection mechanism, however, it's possible that the higher scures toward the end of the training could be due to observer bias. The observers were directly involved with the implementation of the training and may have expected subjects' behaviors to improve. They, in turn, could have projected these expectations onto their ratings, whether subjects actually did improve or not; even though precautions were taken against this possible effect by not allowing observers to see how they had previously rated subjects' behaviors. Another drawback of this data is that it only reflects how subjects behaved in the treatment situation and more reliable data might be obtained by observing the subjects' behavior in their natural environments.

In spite of the questionable results of the training from hard data, the staff were able to observe some other unmeasured changes. These included increased spontaneity within the group, an increased sense of cohesion as a group, and an increased ability of subjects to socialize. with each other and with the staff during unstructured time. Prior to the assertion training, unstructured time during day treatment was usually met with very minimal conversation or silence. By the end of the training, the room would usually be buzzing with conversation during the coffee breaks and other free time.

The subjects from one of the two nursing homes that were represented also developed a rapport with one another that carried over into the nursing' home. Quite often they would help each other out with home- 
work assignments or remind each other to do assignments. At the individual level, one subject who had never before seemed motivated to leave the nursing home called one of her relatives on her own and expressed a desire to eventually move out of the nursing home. This occurred toward the end of the assertion training program. Another subject who very seldom spoke before the training began except to complain about how lonely and depressed he was, could often be seen laughing and smiling as well as conversing animatedly by the end of the training.

Attendance data was encouraging. Out of á possible 32 sessions that subjects could have attended during the eight weeks, the average attendance was 28.1 sessions or $87.8 \%$. Most of the absences were due to illness or appointments (doctor or dental) that conflicted with the day treatment time. All subjects who began assertion training completed it although two were not available a month later for the final data collection.

Completed homework assignments averaged 21.4 out of 31 possible assignments or $69 \%$. This average for homework assignments completed was lower than that for attendance primarily because the two brain damaged subjects, both of whom attended regularly, consistently forgot to do their homework assignments. Interestingly enough, both of these subjects showed increased scores on the Adult Self Expression Scale from pretest to post test.

Some subjects experienced problems doing their homework assignments in their institutional environments. One subject attempted to say something positive about himself to an aide and was told to go talk to the 
R.N. Another subject found it extremely difficult to get anyone to make eye contact with him when he tried to complete an assignment that instructed him to do so. Subjects found that, in general, they received patronizing responses from nursing home staff when they gave compliments or made positive self statements. Certainly, they found that their institutional environment did not offer much reinforcement for their new assertive behaviors when they tried them out. 
CHAPTER VI

IMPLICATIONS FOR FUTURE RESEARCH

Though the results of this study were not statisticaliy significant, other factors mentioned indicate that the elderly can benefit from assertion training and this raises some implications for future research in this area. This research might include both improvement of an assessment device and improvement of the training procedure.

Suggested changes in the assessment procedure, including some already mentioned consist of 1) finding a simpler self-report inventory that addresses the specific life situation of elderly and institutionalized people, and has only binomial responses such as a "yes"/ "no" scale, 2) finding a more reliable observer rating instrument and conducting an inter-rater reliability study among observers, 3) finding a way to obtain data from the nursing homes about changes in the subjects' behaviors and 4) obtaining a larger sampling of subjects.

To improve the training procedures necessitates I) having the same therapist and co-therapist consistently doing the training, 2). follow the reinforcement.. schedule more consistently, 3) use older adults or video tapes of older adults as role models and 4) train nursing home staff to reinforce assertive behaviors among their patients or train the nursing home staff to teach assertive training to the patients themselves so that the staff have an investment in reinforcing the assertive behaviors. 
ADDENDUM

Since program evaluation is related to decision making it seems important to mention the decisions that were made from this evaluation. The elderly day treatment staff at Elahan basically decided two things: 1) they. felt that in spite of the nonsignificance of the hard data the assertion training had been useful to their clients and planned to continue using it as part of the day treatment program focusing on more specific problems that they or the clients identified from week to week and using the behavior rehearsal to practice assertive ways of dealing with these problems, and 2) one of the elderly day treatment staff members adapted the assertion training module used in this study to a group of people she sees as outclients who are all nursing home residents. 
FOOTNOTES

1 Alfred Apsler, "Older Persons Must Show Their Assertiveness," The Columbian (Vancouver, Washington, March 9, 1977).

2 Simone de Beauvoir, old Age (Great Britain: Cox and Wyman, Ltd., 1972), p. 17 .

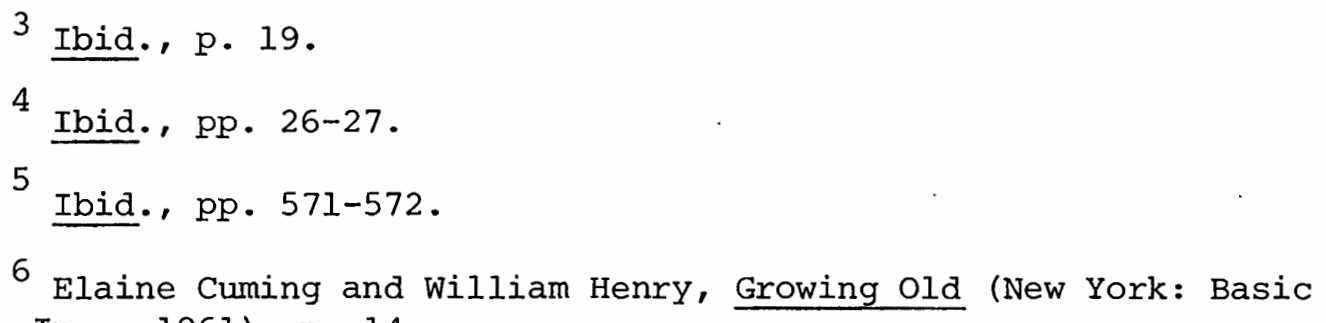
Books, Inc., 1961), p. 14.

7 Mark A. Edinberg, Assertion Training of the Elderly (Ann Arbor, Michigan: University Microfilms, 1977), p. 2 .

8 s. Harsanyi, "Social Attitudes Regarding Aging as a Disability," Journal of Rehabilitation, Vol. 36; No. 6 (1970), pp. 24-27.

9 Ibid., p. 25.

10 R.W. Daley and F. Johnson, "The Effects of Age, Education and Occupation on Psychiatric Dispositions," Social Science and Medicine, Vol. 4 (1970), pp. 619-628.

11 A.B. Hollingshead and F.C. Redlich, Social Class and Mental Illness: A Community Study (New York: J. Wiley and Sons, 1958).

12 Richard M. Garvin and Robert E. Burger, Where They Go to Die: The Tragedy of America's Aged (New York: Delacorte Press, 1968), p. 10. p. 386 .

13 .Erving Goffman, Asylums (Chicago: Adelone Publishing Co., 1961),

14 Garvin and Burger, op. cit., p. 11.

15 Robert Paul Liberman, Larry W. King, William J. DeRisi and Michael McCann, Personal Effectiveness (Champaign, Illinois: Research Press, 1975), p. 7 .

16 Edinberg, op. cit., p. 7.

17 Liberman, King, DeRisi and McCann, op. cit., p. 7. 
18 Edinberg, op. cit., p. 7.

19 Liberman, King, DeRisi and McCann, op. cit., p. 7.

20 Joseph Wolpe, Psychotherapy by Reciprocal Inhibition (Stanford, California: Stanford University Press, 1958), p. 114.

21 James G. Hollandsworth, Jr. and John P. Galassi, "An Assertiveness Inventory for Adults," Journal of Counseling Psychology, Vol. 22, No. 4 (July, 1975), pp. 340-344.

22 Robert E. Alberti, Ph.D. and Michael L. Emmons, Ph.D., Your Perfect Right (San Luis Obispo, California: Impact Publishing Co., 1970), p. 2 .

23

Liberman, King, DeRisi and MCCann, op. cit., p. 7.

24 Ibid., p. 6.

25 A.A. Lazarus, "On Assertive Behavior: A Brief Note," Behavior Therapy, Vol. 4 (1973); pp. 679-699.

26 Claudine Paris and Bill Casey, Project You: A Manual of Rational Assertiveness Training (Denver, Colorado: Institute of Iiving Skills Education, 1976).

27 Liberman, King, DeRisi and McCann, op. cit., p. 144.

28 Ibid., p. 144 .

29 R.H. McFall and A.R. Marston, "An Experimental. Investigation of Behavior Rehearsal in Assertive Training," Journal of Abnormal Psychology, Vol. 76 (1970), pp. 295-303.

30 R.H. McFall and D.B. Lillesand, "Behavior Rehearsal with Modeling and Coaching in Assertive Training," Journal of Abnormal Psychology, Vol. 77 (1971), pp. 313-323.

31 R.M. Eisler, M. Hersen, P.H. Miller and J. Machum, "Shaping Components of Assertive Behavior with Instructions and Feedback," Paper presented at the Association for the Advancement of Behavior Therapy (Miami, 1973).

32 R.H. MCFall and C.T. Twentyman, "Four Experiments on the Relative Contributions of Modeling and Coaching in Assertion Training," Journal of Abnormal Psychology, Vol. 81 (1973), pp. 199-218.

33 Joseph Wolpe and A.A. Lazarus, Behavior Therapy Techniques

(New York: Permagon Press, 1966).

34 Liberman, King, DeRisi and McCann, op. cit., pp. 146-147. 
35 Spencer A. Rathus, "A 30-Item Schedule for Assessing Assertive Behavior," Behavior Therapy, Vol. 4 (1973), pp. 398-406.

36 John P. Galassi et. all, "The Adult Self Expression Scale: A Measure of Assertiveness," On file at Elahan Mental Health Clinic.

37 Melvin L. Gay, James G. Hollandsworth, Jr. and John P. Galassi, "An Assertiveness Inventory for Adults," Journal of Counseling Psychology, Vol. 22, No. 4 (July, 1975), pp. 340-344.

38 Liberman, King, DeRisi and McCann, op. cit., pp. 144-145.

39 R.H. MCFall and A.R. Marston, "An Experimental Investigation of Behavior Rehearsal in Assertive Training," Journal of Abnormal Psychology, Vol. 76 (1970), pp. 295-303.

40 J.F. Lomont, N.J. Spector and K.K. Skinner, "Group Assertion Training and Group Insight Therapies," Psychological Reports, Vol. 25 (1969), pp. 463-470.

41 C.D. Booraem and J.V. Flowers, "Reduction of Anxiety and Personal Space as a Function of Assertion Training with Severely Disturbed Neuropsychiatric Patients," Psychological Reports, Vol. 30 (1972), pp. 923-929.

42 Lawrence P. Percell, "The Effect of Assertive Training on Modifying Cognitive and Affective Variables," Newsletter for Research in Mental Health and Behavioral Sciences, Vol. 15, No. 4 (Nov., 1973), pp. 20-22 and Lawrence P. Percell, "The Correlations Among Assertiveness and Some Cognitive and Affective Variables," Newsletter for Research in Mental Health and Behavioral Sciences, Vol. 15, No. 3 (1973), pp. 25-26.

43 R.M. Eisler, P.M. Miller and M. Hersen, "Components of Assertive Behavior," Journal of Clinical Psychology, Vol. 29 (1973), pp. 295-299.

44 Nan Corby, "Assertion Training with Aged Populations," The Counseling Psychologist, Vol. 5, No. 4 (1975), p. 69.

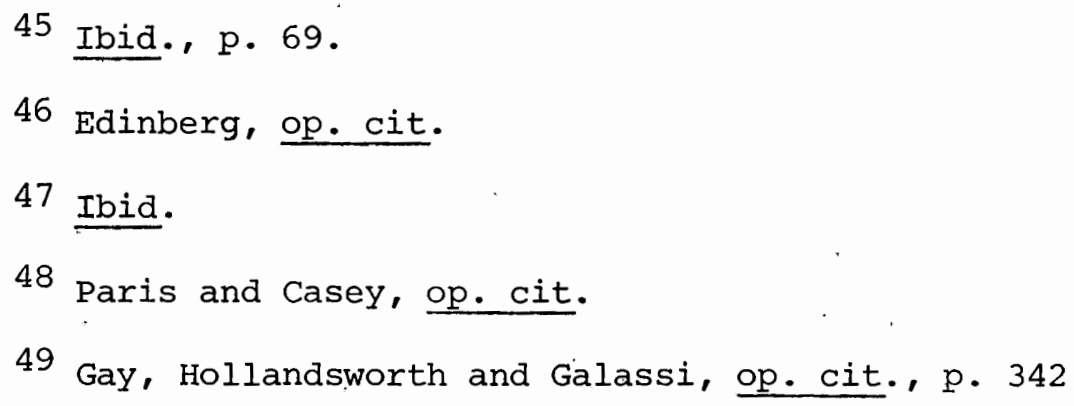




\section{A SELECTED BIBLIOGRAPHY}

Alberti, Robert E., Ph.D. and Emmons, Michael L., Ph.D. Your Perfect Right. San Luis Obispo, California: Impact Publishing Co., 1970 .

Apsler, Alfred. "Older Persons Must Show Their Assertiveness." The Columbian. Vancouver, Washington. March 9, 1977. 1972 .

Beauvoir, Simone de. Old Age. Great Britain: Cox and Wyman, Ltd.,

Booraem, C.D. and Flowers, J.V. "Reduction of Anxiety and Personal Space as a Result of Assertion Training with Severely Disturbed Neuropsychiatric Patients." Psychological Reports, vol. 30, 1972.

Corby, Nan. "Assertion Training with Aged Populations." The Counseling Psychologist, vol. 5, no. 4, 1975.

Cumming, Elaine and Henry, William. Growing Old. New York: Basic Books, Inc., 196I.

Daley, R. and Johnson, F. "The Effects of Age, Education and Occupation on Psychiatric Dispositions." Social Science and Medicine, vol. 4, 1970.

Edinberg, Mark A. Assertion Training of the Elderly. Ann Arbor, Michigan: University Microfilms, 1977.

Eisler, Richard M.; Miller, Peter M. and Hersen, Michael. "Components of Assertive Behavior." Journal of Clinical Psychology, vol. 29, 1973.

Eisler, Richard M.; Hersen, Michael; Miller, Peter and Machum, J. "Shaping Components of Assertive Behavior with Instructions and Feedback." (paper presented at the Association for the Advancement of Behavior Therapy, Miami, 1973).

Galassi, John P. et. all. "The College Self Expression Scale: A Measure of Assertiveness." (article on file at Elahan Mental Health Clinic).

Galassi, John P. and Galassi, Merna D. "Validity of a Measure of Assertiveness." Journal of Counseling Psychology, vol. 21, 1974. 
Gambrill, Eileen D. and Richey, Cheryl A. "An Assextion Inventory for Use in Assessment and Research." Behavior Therapy, vol. 6, 1975.

Garvin, Richard M. and Burger, Robert E. Where They Go to Die: The Tragedy of America's Aged. New York: Delacorte Press, 1968.

Gay, Melvin L.; Hollandsworth, James G., Jr. and Galassi, John P. "An Assertiveness Inventory for Adults:" Journal of Counseling Psychology, vol. 22, no. 4, 1975.

Goffman, Erving. Asylums. Chicago: Adelone Publishing Co., 1961.

Harsanyi, S. "Social Attitudes Regarding Aging as a Disability." Journal of Rehabilitation, vol. 36, no. 6, 1970.

Hersen, Michael; Eisler, Richard M. and Miller, Peter M. "An Experimental Analysis of Generalization in Assertion Training." Behavior Response and Therapy, vol. 12, 1974.

Hollingshead, A.B. and Redlich, F.C. Social Class and Mental Illness: A Community Study. New York: J. Wiley and Sons, 1958.

Lazarus, A.A. "On Assertive Behavior: A Brief Note." Behavior Therapy, vol. 4, 1973 .

Liberman, Robert Paul; King, Larry W.; DeRisi, William J. and McCann, Michael. Personal Effectiveness. Champaign, Illinois: Research Press, 1975.

Lomont, J.F.; Spector, N.J. and Skinner, K.A. "Group Assertion Training and Group Insight Therapies." Psychological Reports, vol. 30, 1972 .

McFall, R.H. and Lillesand, D.B. "Behavior Reheersal with Modeling and Coaching in Assertion Training." Journal of Abnormal Psychology, vol. 77, 1971.

McFall, R.H. and Marston, A.R. "An Experimental Investigation of Behavior Rehearsal in Assertive Training." Journal of Abnormal Psychology, vol. 76, 1970.

McFall, R.H. and Twentyman, C.T. "Four Experiments on the Relative Contributions of Rehearsal, Modeling and Coaching to Assertion Training." Journal of Abnormal Psychology, vol. 81, 1973.

Paris, Claudine and Casey, Bill. Project You: A Manual of Rational Assertiveness Training. Denver, Colorado: Institute of Living Skills Education, 1976. 
Percell, Lawrence P. "The Correlations Among Assertiveness and Some Cognitive and Affective Variables." Newsletter for Research in Mental Health and Behavioral Sciences, vo1. 15, no. 3, 1973.

Percell, Lawrence P." "The Effect of Assertive Training on Modifying Cognitive 'nd Affective Variables." Newsletter for Research in Mental Health and Behavioral. Sciences, vol. 15, no. 4, 1973.

Phelps, Stanlee and Austin, Nancy. The Assertive Woman. Fredricksberg, Virginia: Impact Publishing Co., 1975.

Rathos, Spencer A. "A 30-Item Schedule for Assessing Assertive Behavior." Behavior Therapy, vol. 4, 1973.

Wolpe, Joseph. Psychotherapy by Reciprocal Inhibition. Stanford, California: Stanford University Press, 1958.

Wolpe, Joseph. The Practice of Behavior Therapy. New York: Pergamon Press, 1958.

Wolpe, Joseph and Lazarus, A.A. Behavior Therapy Techniques. New York: Pergamon Press, 1966. 
APPENDIX A

THE ASSERTION TRAINING PROGRAM

This assertion training program covers eight primary objectives, one each week for eight weeks of four sessions each. Format will be felxible enough to allow for review of previously taught concepts when necessary.

WEEK ONE

Objective: Think and Talk About Yourself in a Positive Way.

Session 1: Write down three things you like about yourself. Then share these with the rest of the group and discuss how it feels to talk about yourself in this way.

Homework Assignment: Write down three positive thoughts about yourself to share in the group tomorrow. They must be different from the ones you shared today.

Session 2: Role play a conversation with someone else in the group in which you say at least one positive thing about yourself. Homework: During a conversation with someone else you know well, say at least one positive thing about yourself.

Session 3: Role play a conversation pretending to be talking to one of the nurses or aides where you reside and say something positive about yourself.

Homework: Say something positive about yourself to one of the nurses or aides where you reside.

Session 4: Role play a conversation where you tell another person of a situation you handled successfully this week (a success story).

Homework: Tell another person at least one success story over the weekend. 
WEEK TWO

Objective: Feel Comfortable Expressing and Receiving Honest Compliments.

Session 1: Write down one thing you like.:about the person sitting to your left and then share what you have written with that person practicing eye contact and smiling. The person receiving the compliment should acknowledge it also practicing eye contact and smiling. Homework: Smile at someone you don't know very well, using eye contact and notice how they react or respond to you.

Session 2: Role play a conversation in which you give a compliment to someone you know well.

Homework: Compliment someone you know well on something you

like about them. Be Specific. Remember to use eye contact and smile.

Session 3: Role play a conversation in which you share your appreciation with someone for a favor they have done for you recently. Homework: Express your appreciation to someone for a favor they have done for you. Be specific.

Session 4: Role play a conversation where you give a compliment to one of the nurses or aides where you reside.

Homework: Give two compliments over the weekend, one of them to a nurse or aide and make two positive self statements in conversations with other people.

WEEK THREE

Objective: Feel Comfortable Expressing Your Opinions and Feelings to others.

Session 1: State your opinion about something to the group. Then role play a conversation with one other person in which you state an opinion about something.

Homework: Tell another person your opinion about something and ask the other person for his or her opinion about the subject.

Session 2: State a feeling you are having to the group. Then role play a conversation in which you share a feeling you're having with the other person:

Homework: Tell another person about a feeling you're having.

Session 3: Role play a conversation in which you state your opinion about what the other person is saying.

Homework: State your opinion to another person about what they are saying to you in a conversation. 
Session 4: Role play a conversation in which you state either an opinion or a feeling to the other person.

Homework: Express an opinion or a feeling to someone over the weekend.

WEEK FOUR

Objective: Ask For What You Want.

Session 1: Role play a conversation in which you ask someone

else their opinion about something.

Homework: Ask someone their opinion about something.

Session 2: Role play a conversation in which you ask the other person to clarify (explain) something they say.

Homework: Ask another person to clarify something they say to you.

Session 3: Role play a conversation in which you ask another person to do a favor for you.

Homework: Ask someone to do a favor for you.

Session 4: Role play a conversation in which you ask someone to do an activity with you.

Homework: Invite someone to do an activity with you.

WEEK FIVE

Objective: State Honest Disagreements with Ease.

Session 1: Role play a conversation in which you disagree with something the other person says.

Homework: Disagree with something another person says to you and tell them that you disagree. sion.

Session 2: Play the "devil's advocate" in a small group discus-

Homework: Find a newspaper article or something on television, on the radio or in a magazine that you disagree with and share it in the group tomorrow.

Session 3: Share the newspaper article, radio, telvision or magazine opinion with the group and tell why you disagree. Allow others in the group to give their opinions.

Homework: During a conversation with someone tell them about the newspaper, magazine, radio or television opinion with which you disagree and why. 
Session 4: Role play using the task cards (index cards with specific situations described on them) practicing the assertive behaviors you have learned so far.

Homework: Disagree with three different people over the weekend.

WEEK SIX

Objective: Be Able to Say "No" when You Want To.

Session. I: Role play refusing to take something you don't want when it's offered to you.

Homework: Think of one situation where you have difficulty saying "no" to share in the group tomorrow.

Session 2: Share the situation you thought of for yesterday's homework assignment and then role play the situation practicing saying "no." Then add the situation to the task cards for future role playing.

Homework: Count how many times you feel like saying "no" and whether you did or not.

Session 3: Role play a situation in which someone asks you to do a favor that you don't want to do and you refuse.

Homework: Same as yesterday only try to increase the number of times you say "no" when you want to.

Session 4: Role play situations on the task cards. Homework: Same as yesterday.

WEEK SEVEN

Objective: Insist on Fair Treatment.

Session 1: Role play a conversation where you ask a question about something you don't understand of someone who might know the answer.

Homework: Ask someone two questions about some subject that they might be knowledgeable in.

Session 2: Role play calling up some agency (the bus service, social security, legal aid, the telephone company, a business) to find out information about their services and your rights/ eligibility. Homework: Ask a staff member at your residence for a copy of your legal rights as a patient in a nursing home.

Session 3: Discuss your rights as a patient and share a situa- 
tion where you think your rights were violated. Role play this situation and insist on your rights.

Homework: Think of a situation where you feel you were not treated fairly to share in the group tomorrow.

Session 4: Role play the situation you thought of for yesterday's assignment and handle it assertively.

Homework: Join in on an activity or a conversation in which other people are already participating over the weekend.

WEEK EIGHT

Objective: Initiate and Maintain Social Contacts.

Session I: Role play that you are introducing yourself to someone you don't know.

Homework: Introduce yourself to someone at your residence who . you don't know very well.

Session 2: Role play a situation in which you initiate a conversation with someone you don't know very well.

Homework: Initiate a conversation with someone you don't know very well and keep the conversation going by asking questions and giving your opinion.

Session 3: Role play a conversation in which you invite someone you don't know very well to join you in an activity and ask this person questions to get his or her opinion.

Homework: Invite someone who you don't know very well to join you in an activity and ask this person questions to get his or her opinion.

Session 4: Role play a situation where you are involved in a conversation with someone that you don't know very well and keep the conversation going.

Homework: Initiate a conversation with someone you don't know very well and time how long you can keep it going.

After this eight week training phase is over the task cards may be used to continue practicing and reinforcing these skills. 
APPENDIX B

THE ADULT SELF EXPRESSION SCALE ADAPTED FOR

THE ELDERLY 


\section{TTE ADULT SELF EXPRESSIOH SCALE.}

THE FOL OWING INNENTORY IS DESIGNED TO PROVIDE INFORMATION ABOUT THE WAY IN WHICH YOU EXPRESS YOURSELF. PLEASE ANSWER THE QUESTIONS BY MARKING THE APPROPRIATE COLUMN FOLLOWING EACH QUESTION. YOUR ANSWER SHOUD INDICATE HOW YOU WOUD GENERALIY BEHAVE IN THAT SITUATION. IF A PARTICULAR SITLATION DOES NOT APPLY TO YOU, ANSWER THE WAY YOU THINK YOU WOULD RESPOND IF YOU WERE IN THAT SITLATION, YOUR ANSWER SHOULD NOT REFLECT HOW YOU THINK YOU OUGHT TO ACT OR HOW YOU WOULD LIKE TO ACT. PLEASE WORK AS QUICKLY AS YOU CAN AND DON'T SPEND A LOT OF TIME ON ANY ONE QUESTION, YOUR FIRST RESPONSE IS PROBABLY THE MOST ACCURATE ONE.

\begin{tabular}{|c|c|c|c|c|c|}
\hline QUESTIOAS: & $\begin{array}{l}\text { ALMOST ALWAYS } \\
\text { OR ALWAYS }\end{array}$ & USLALYY & SOMETIMES & SEI DOM & $\begin{array}{l}\text { INEVER OR } \\
\text { RARELY } \\
\end{array}$ \\
\hline 1. DO YOU IGNORE IT WHEN SOMEONE PLSHES IN FRONT OF YOU IN LINE? & & & & & \\
\hline 2. DO YOU FIND IT DIFFICUTT TO ASK A FRIEND TO DO A FAVOR FOR YOU? & & & & & \\
\hline $\begin{array}{l}\text { 3. IF YOUR NLRSE OR SUPERVISOR MAKES WHAT YOU CONSIDER TO BE AN UNREASONABLE } \\
\text { REQUEST, DO YOU HAVE DIFFICULTY SAYING "NO"? }\end{array}$ & & & & & \\
\hline $\begin{array}{l}\text { 4. ARE YOU RELUCTANT TO SPEAK TO AN ATTRACTIVE ACQLAINTANCE OF THE } \\
\text { OPPOSITE SEX? }\end{array}$ & & & & & \\
\hline $\begin{array}{l}\text { 5. IS IT DIFFICULT FOR YOU TO REFUSE UNREASONABLE REQUESTS FROM YOUR } \\
\text { CHILDREN? }\end{array}$ & & & & & \\
\hline $\begin{array}{l}\text { 6. DO YOU FIND IT DIFFICULT TO ACCEPT COMPLIMENTS FROM YOUR NLRSE OR } \\
\text { SUPERVISOR? }\end{array}$ & & & & & \\
\hline 7. DO YOU EXPRESS YOUR NEGATIVE FEELINGS TO OTHERS WHEN IT IS APPROPRIATE? & & & & & \\
\hline $\begin{array}{l}\text { 8. DO YOU FREELY VOLLNTEER INFORNATION OR OPINIONS IN DISCUSSIONS WITH } \\
\text { PEOPLE WHOM YOU DO NOT KNOW VERY WEUL? }\end{array}$ & . & & & & \\
\hline $\begin{array}{l}\text { 9. IF THERE WAS A PUBLIC FIGURE WHOM YOU GREATLY ADNIRED AND RESPECTED } \\
\text { AT A LARGE SOCIAL GATIERING, WOULD YOU MAKE AN EFFORT TO INTRODUCE } \\
\text { YOLRSELF? }\end{array}$ &. & & & & \\
\hline 10. HOW OFTEN DO YOU EXPRESS JUSTIFIED FEELINGS OF ANGER TO YOUR CHILDREN? & & & & & \\
\hline $\begin{array}{l}\text { 11. IF YOU HAVE A FRIEND OF WHOM YOUR CHILDREN DO NOT APPROVE, DO YOU MAKE } \\
\text { AN EFFORT TO HELP THEM GET TO KNOW ONE ANOTHER BETTER? }\end{array}$ & & & & & \\
\hline $\begin{array}{l}\text { 12. IF YOU WERE WATCHING A TN PROGRAM IN WHICH YOU WERE VERY INTERESTED AND } \\
\text { A CLOSE RELATIVE WAS DISTURBING YOU, WOULD YOU ASK THEM TO BE QUIET? }\end{array}$ & & & & & \\
\hline
\end{tabular}


$-2-$

\begin{tabular}{|c|c|c|c|c|c|}
\hline & $\begin{array}{l}\text { ALMOST ALWAYS } \\
\text { OR ALWAYS } \\
\end{array}$ & USUALLYY & SONETIMES & SELDOM & $\begin{array}{c}\text { TheVER OR } \\
\text { RARELY }\end{array}$ \\
\hline \multicolumn{6}{|l|}{$\begin{array}{l}\text { 13. DO YOU PLAY AN IMPORTANT PART IN DECIDING HOW YOU AND YOUR CLOSE FRIENDS } \\
\text { SPEND YOUR LEISLRE TINE TOGETERE }\end{array}$} \\
\hline \multicolumn{6}{|l|}{$\begin{array}{l}\text { 14. IF YOU ARE ANGRY AT YQUR SPOUSE/BOYFRIEND OR GIRLFRIEND, IS IT DIFFICULT } \\
\text { FOR YOU TO TEUL THEM? }\end{array}$} \\
\hline \multicolumn{6}{|l|}{$\begin{array}{l}\text { 15. IF AFRIEND WHO IS SUPPOSED TO PICK YOU UP FOR AN IMPORTANT ENGAGEMENT } \\
\text { CALS FIFTEEN MINUTES BEFORE YE/SHE IS SUPPOSED TO BE THERE AND SAYS } \\
\text { THEY CANNOT MAKE IT, DO YOU EXPRESS YOUR ANNOYANCE? }\end{array}$} \\
\hline \multicolumn{6}{|l|}{$\begin{array}{l}\text { 16. IF YOU APPROVE OF SOMETHING YOUR CHILDREN DO, DO YOU EXPRESS YOUR : } \\
\text { APPROVAL? }\end{array}$} \\
\hline \multicolumn{6}{|l|}{$\begin{array}{l}\text { 17. IF IN A RUSH YOU STOP BY A STORE TO PICKUP A FFW ITEMS, WOUD YOU ASK } \\
\text { TO GO BEFORE SONEONE IN MHE CHECK OUT LINE? }\end{array}$} \\
\hline \multicolumn{6}{|l|}{ 18. DO YOU FIND IT DIFFICUT TO REFUSE REQUESTS OF OTHERS? } \\
\hline \multicolumn{6}{|l|}{$\begin{array}{l}\text { 19. IF YOUR NURSE OR SUPERVISOR EXPRESSES OPINIONS WITH WHICH YOU STRONGLY } \\
\text { DISAGREE, DO YOU VENTURE TO STATE YOUR OWN POINT OF VIEW? }\end{array}$} \\
\hline \multicolumn{6}{|l|}{ 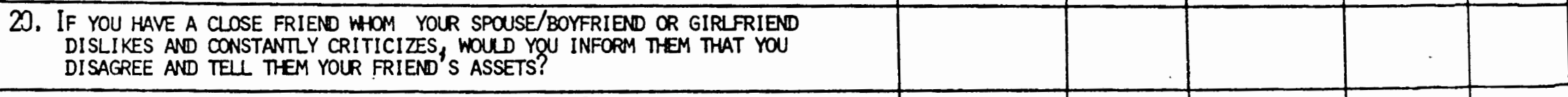 } \\
\hline \multicolumn{6}{|l|}{ 21. DO YOU FIND IT DIFFICULT TO ASK FAVORS OF OTHERS? } \\
\hline \multicolumn{6}{|l|}{$\begin{array}{l}\text { 22. If FOOD WHICH IS NOT TO YOUR SATISFACTION WAS, SERYED IN A } 6000 \\
\text { RESTAURANT, WOUD YOU BRING IT TO THE WAITER'S ATIENTION? }\end{array}$} \\
\hline \multicolumn{6}{|l|}{ 23. DO YOU TEND TO DRAG OUT YOLR APOLOGIES? } \\
\hline \multicolumn{6}{|l|}{ 24. WHEN NECESSARY, DO YOU FIND IT DIFFICULT TO ASK FAVORS OF YOUR CHILRREN? } \\
\hline \multicolumn{6}{|l|}{ 25. DO YOU INSIST THAT OTHERS DO THEIR FAIR SHARE OF THE WORK? } \\
\hline \multicolumn{6}{|l|}{ 26. DO YOU HAVE DIFFICULTY SAYING "NO" TO SALESMEN? } \\
\hline $\begin{array}{l}\text { 27. ARE YOU RELUCTANT TO SPEAK UP IN A DISCUSSION WITH A SMALL GROUP OF } \\
\text { FRIENDS? }\end{array}$ & & & & & \\
\hline
\end{tabular}


$-3$

\begin{tabular}{|c|c|c|c|c|c|}
\hline & $\begin{array}{l}\text { ALMOST ALWAYS } \\
\text { OR ALWAYS }\end{array}$ & USLAUYY & SOMETIMES & SELDOM & $\begin{array}{l}\text { NeVER OR } \\
\text { RARELYY }\end{array}$ \\
\hline $\begin{array}{l}\text { 23. DO YOU EPPRESS ANGER OR ANNOYANCE TO YOU NURSE OR SUPERVISOR WHEN } \\
\text { IT IS JUSTIFIED? }\end{array}$ & & & & & \\
\hline 29. DO YOU COMPLIMENT AND PRAISE OTHERS? & & & & & \\
\hline $\begin{array}{l}\text { 30. DO YOU HAVE DIFFICULT ASKING A CLOSE FRIEND TO DO AN IMPORTANT } \\
\text { FAVOR EVEN THEOUGH IT WILL CAUSE THEM AN INCONENIENCE? }\end{array}$ & & & & & \\
\hline $\begin{array}{l}\text { 31. IF A CLOSE RELATIVE MAKES WHAT YOU CONSIDER TO BE AN UNREASONABLE } \\
\text { REQLEST, DO YOU HAVE DIFFICULTY SAYING "NO"? }\end{array}$ & & & & & \\
\hline $\begin{array}{l}\text { 32. IF YOUR NURSE OR SUPERVISOR MAKES A STATEMENT THAT YOU CONSIDER UNIRLE, } \\
\text { DO YOU QUESTION IT ALDLD? }\end{array}$ & & & & & \\
\hline $\begin{array}{l}\text { 33. IF YOU FIND YOURSEL BECOMING FOND OF A RRIEND, DO YOU HAVE DIFFICUTTY } \\
\text { EXPRESSING THESE FEELINGS TO THAT PERSON? }\end{array}$ & & & & & \\
\hline $\begin{array}{l}\text { 34. DO YOU HAVE DIFFICUTY EXCHANGING A PURCHASE WITH WHICH YOU ARE } \\
\text { DISSATISFIED? }\end{array}$ & & & & & \\
\hline $\begin{array}{l}\text { 35. IF SOMEONE IN AUTHORITY INTERRUPTS YOU IN THE MIDDLE OF AN IMPORTANT } \\
\text { CONERSATION, DO YOU REQLEST THAT THAT PERSON WAIT UNTIL YOU ARE } \\
\text { FINISHED? }\end{array}$ & & & & & \\
\hline $\begin{array}{l}\text { 36. IF A PERSON OF THE OPPOSITE SEX WHOM YOU HAVE BEEN WANTING TO MEET } \\
\text { DIRECTS ATTENTION TO YOU AT A PARTY, DO YOU TAKE THE INITIATIVE IN } \\
\text { BEGINNING THE CONVERSATION? }\end{array}$ & . & & & & \\
\hline $\begin{array}{l}\text { 37. Do YOU HESITATE TO EXPRESS RESENTMENT TO A FRIEND WHO HAS UNULSTIFIABLY } \\
\text { CRITICIZTD YOU? }\end{array}$ & & & & & \\
\hline $\begin{array}{l}\text { 38. IF YOUR CHILDREN WANTED YOU TO CONE HONE FOR A WEEKEND VISIT AND YOU } \\
\text { HAD MADE IMPORTANT PLANS, WOUD YOU CHANGE YOUR PLANS? }\end{array}$ & 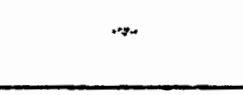 & & & & \\
\hline 39. ARE YOU RELUCTANT TO SPEAK UP IN A DISCUSSION OR DEBATE? & & & & & \\
\hline $\begin{array}{l}\text { 40. IF A FRIEND WHO HAS BOPROWED } \$ 5.00 \text { FROM YOU SEENS TO HAVE FORGOTTEN } \\
\text { ABOUT IT, IS IT DIFFICULT FOR YOU TO REMIND THIS PERSON? }\end{array}$ & & & & & \\
\hline $\begin{array}{l}\text { 41. IF YOUR NURSE OR SUPERVISOR TEASES YOU TO THE POINT THAT IT IS NO } \\
\text { LONGER FUN, DO YOU HAVE DIFFICLITY EXPRESSING YOUR DISPLEASURE? }\end{array}$ & . & & & & \\
\hline
\end{tabular}




\section{$-4$}

\begin{tabular}{|c|c|c|c|c|c|}
\hline & $\begin{array}{l}\text { AUMOST AWMAYS } \\
\text { OR A WWAYS }\end{array}$ & USLALYY & Sometimes & SELDOM & $\begin{array}{ll}\text { NEVER OR } \\
\text { RAREIY } \\
\end{array}$ \\
\hline $\begin{array}{l}\text { 42. IF YOUR SPPOSE/BOYFRIEND OR GIRLERIEND IS BLATANTYY LWFAIR, DO } \\
\text { YOU FIND IT DIFFICULT TO SAY SONETHNG TO TIEP? }\end{array}$ & & & & & \\
\hline 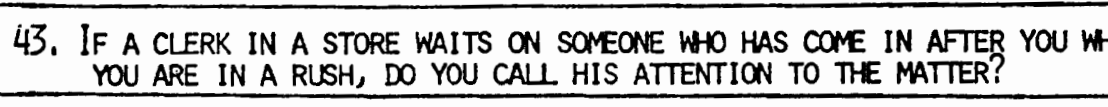 & & & & & \\
\hline 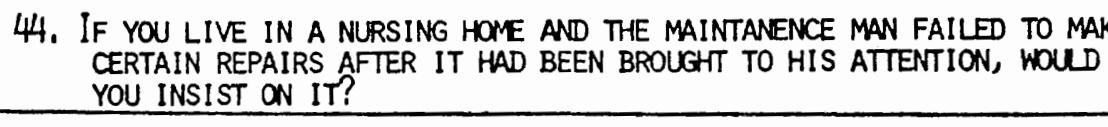 & & & & & \\
\hline $\begin{array}{l}\text { 45. Do YOU FIND IT DIFFICUT TO ASK YOUR NURSE OR SUPERVISOR FOR SONETT } \\
\text { YOU NEED? }\end{array}$ & & & & & \\
\hline $\begin{array}{l}\text { 46. Do YOU HAVE DIFFICUTY VERBALIY EXPRESSING LOVE AND AFFECTION TO } \\
\text { YOUR SPOUSE/ BOYFRIEND OR GIRLRILED? }\end{array}$ & - & & & & \\
\hline 47. DO YOU READILY EXPRESS YOUR OPINIONS TO OTHERS? & & & & & \\
\hline $\begin{array}{l}\text { 48. IF A FRIEND MAKES WHAT YOU CONSIDER TO BE AN LNREASONABLE REQLEST, } \\
\text { ARE YOU ABLE TO REFLSE? }\end{array}$ & & & & & \\
\hline
\end{tabular}


APPENDIX C

OBSERVER RATING FORM 
I. NAME QF CLIENT

OBSERVER

II. THERAPIST RATING OF CLIENT IN ROLE PIAYING SITUATIONS:

1. Rate the client on a scale from one to ten as to how much eye contact you fee] he or she had with the people with whom he/she was interacting durilıg the role play situation. $10=$ continuous eye contact

1 = none at all

2. Rate the client's tone of voice on a scale from one to ten as to how clearly he/she could be heard during the role play situation.

$$
\begin{aligned}
10= & \text { loud and clear } \\
1= & \text { could not be heard } \\
& \text { at all }
\end{aligned}
$$

3. Rate the client's anxiety level on a scale from one to ten as you perceive it.

$10=$ no anxiety at all

1 = very anxious

4. Rate the client's behavior on a scale from one to ten as to how assertive you feel he/she was in the role play situation in rela-

\begin{tabular}{|c|c|c|c|c|c|c|c|c|}
\hline DATE: & $2-14$ & $2-21$ & $2-28$ & $3-7$ & $3-14$ & $3-21$ & $3-28$ & $4-4$ \\
\hline RATING: & & & & & & & & \\
\hline 1. Eye contact & & & & & & & & \\
\hline 2. Voice volume & & & & & & & & \\
\hline 3. Anxiety & & & & & & & & \\
\hline $\begin{array}{l}\text { 4. Assertive- } \\
\text { ness }\end{array}$ & & & & . & & & & \\
\hline
\end{tabular}
tion to the stated objective for the session.

$$
\begin{aligned}
10 & =\text { very assertive } \\
1 & =\text { not assertive at al1 }
\end{aligned}
$$

III. USE THIS SPACE AND THE BACK OF THIS PAGE FOR ANY ADDITIONAL OBSERVATIONS NOT INCLUDED ABOVE. 